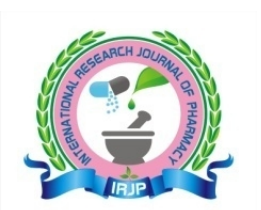

INTERNATIONAL RESEARCH JOURNAL OF PHARMACY

www.irjponline.com

ISSN $2230-8407$

\title{
Research Article \\ DESIGN AND DEVELOPMENT OF TASTE MASKED ORAL DISINTEGRATING TABLET OF ONDANSETRON HYDROCHLORIDE
}

N. G. Raghavendra Rao ${ }^{1}$, B. Sanjeeva Nayak ${ }^{1}$, B. Santhosh Kumar ${ }^{1}$, C. Kistayya ${ }^{2}$

${ }^{1}$ Department of Pharmaceutics, Sree Chaitanya Institute of Pharmaceutical Science, L.M.D. Colony, Karimnagar, Telangana, India

${ }^{2}$ Department of Pharmaceutical Chemistry, St. Johns College of Pharmaceutical Science, Yerrakota, Yemmiganur, Kurnool, Andhra Pradesh, India

*Corresponding Author Email: ngraghu@rediffmail.com

Article Received on: 11/07/16 Revised on: 03/08/16 Approved for publication: 16/08/16

DOI: $10.7897 / 2230-8407.07897$

\begin{abstract}
Ondansetron $\mathrm{HCl}$ is effective in the treatment of nausea and vomiting caused in such condition it is difficult to administer drug with a glass of water; hence it is beneficial to administer such drugs as orodispersible. Thus in the present study an attempt has been made to mask the taste of Ondansetron $\mathrm{HCl}$ and to formulate orodispersible with good mouth feel so as to prepare a "patients friendly dosage form.". The tablets prepared by sublimation method. The prepared tablets were evaluated for various pharmaceutical characteristics such as hardness, \% friability, weight variation, drug content all the results were within the IP. Limit. The tablets prepared possess a weight variation in the range 99 to $101 \mathrm{mg}$ which is below $\pm 7.5 \%$, hardness of 2.7 to $3.0 \mathrm{~kg} / \mathrm{cm}^{2}$, percentage friability of 0.42 to $0.73 \%$. The wetting time of Ondansetron $\mathrm{HCl}$ fast dissolving tablets was found to be in the range of 44 to $81 \mathrm{sec}$. The prepared formulations shows water absorption ratio in the range of 72 to $85 \%$. The percentage drugs content of the tablets were found to be between 98.24 to $101.20 \%$ of Ondansetron $\mathrm{HCl}$. In-vitro disintegration time the formulations OHS4 and OHS 8 were found to be promising and showed a $28 \mathrm{sec}$ and $32 \mathrm{sec}$ respectively. Based on the in-vitro disintegration time and dissolution studies formulations OHS4 and OHS8 were found to be promising and showed a disintegration time of $28 \mathrm{sec}$ and $32 \mathrm{sec}$ respectively. Formulation OHS4 containing camphor showed highest drug release $99 \%$ within 8 min. Formulation OHS 8 showed highest drug release $90 \%$ within 8 min. From FTIR and DSC study results reveals that there is no interaction between drug and any other formulation excipients. In case of stability study there is decrease in disintegration time, wetting time was observed. The results concluded that fast dissolving tablets of Ondansetron HCl showing enhanced dissolution will lead to improved bioavailability and effective therapy. This drug resin complex was compressed in tablets by adding diluents to see its mouth feel properties and bitter taste is masked.
\end{abstract}

Key words: Fast dissolving tablets, Ondansetron Hydrochloride, superdisintegrants, sublimation Method.

\section{INTRODUCTION}

Fast dissolving dosage form can be disintegrated, dissolved or suspended by saliva in mouth. The fast dissolving tablets disintegrates instantaneously when placed on tongue and releases the drug dissolve or disperses in saliva ${ }^{1}$. The fast dissolving tablets are useful in patients ${ }^{2-3}$, like pediatric, geriatric, bedridden or mentally disabled, who may face difficulty in swallowing conventional tablet or capsule ${ }^{4}$ leading to ineffective therapy ${ }^{5}$. Most pharmaceutical forms for oral administration are formulated for direct ingestion or for chewing or for prior dispersion/dissolution in water. Some of them are absorbed in mouth to obviate the problem associated with conventional dosage forms orally fast dissolving tablet have been developed which combine hardness, dosage uniformity, stability and other parameters, since no water is required for swallowing the tablets and they are thus suitable for geriatric, pediatric and traveling patients ${ }^{6}$. The fast dissolving tablet formulation is defined by the food and drug administration (FDA) as, A solid dosage form containing medicinal substances which disintegrates rapidly, usually within matter of seconds, when placed upon the tongue ${ }^{7}$. These FDT are designed to dissolve or disintegrates rapidly in saliva generally within $<60 \sec ^{8}$.

Ondansetron $\mathrm{HCl}$ is a potent selective serotonin 5HT3 receptor antagonist which has a role in prophylaxis of postoperative chemotherapy/radiotherapy induced emesis. The adult dose is $8 \mathrm{mg}^{9}$. This makes Ondansetron $\mathrm{HCl}$ a suitable candidate for fast dissolving dosages form. Half life of Ondansetron Hydrochloride is 4-6 hrs and undergoes extensive first pass metabolism, Oral Ondansetron Hydrochloride appear efficacious and has been shown to have some clinical advantages over aspirin and ibuprofen ${ }^{9}$. Ondansetron $\mathrm{HCl}$ oral bioavailability is about $90 \%$ in healthy volunteers when taken with food, which increases absorption by more than $50 \%$. Peak plasma concentration occurs in $2.5-5 \mathrm{hrs}^{10}$. Hence, in the present research work Ondansetron Hydrochloride fast dissolving tablets were prepared by Sublimation technique by using different subliming agents like camphor, urea and menthol ${ }^{11}$. Ondansetron $\mathrm{HCl}$ orodispersible tablets with good mouth feel so as to prepare patients friendly dosage form.

\section{MATERIALS AND METHODS}

Ondansetron Hydrochloride drug is procured as a gift sample from Dr Reddy Lab Hyderabad, India. Crosspovidone was procured as a gift sample from Signet (Mumbai), Mannitol, MCC, aspartame, camphor, urea, menthol, talc and magnesium stearate purchased from SD. Fine chem., Mumbai. All other materials were of analytical reagent grade. 
Drug-excipients compatibility studies: Fourier Transform Infrared Spectroscopy (FTIR) and Differential Scanning Colorimetry.

Solubility Study: The solubility of Ondansetron $\mathrm{HCl}$ แล determined in water and different $\mathrm{pH}$ buffers. The solubility study was conducted by taking excess amount of the drug in the $100 \mathrm{ml}$ of the solution and the solutions were kept for 28 $\mathrm{hr}$. Then the solutions were filtered and diluted with sufficient amount of the same solvent. The absorbance of the solutions was determined at $249 \mathrm{~nm}$.

\section{Methods of preparation of Ondansetron hydrochloride fast dissolving tablets ${ }^{12-13}$}

Preparation of drug resin complex: An accurately weighed amount of resin particles (Kyron-T-154) were suspended in deionized Water for $15 \mathrm{~min}$. to allow uniform swelling of polymer, after which Ondansetron $\mathrm{HCl}$ was added and slurry was stirred with the help of Magnetic stirrer for $45 \mathrm{~min}$ to allow the maximum adsorption of drug on to the resin. Resinate thus formed was filtered and washed with deionized Water. It was then dried at $50^{\circ} \mathrm{C}$ and the drug content was determined Spectrometrically at $249 \mathrm{~nm}$.

Sublimation method: The basic principle involved in preparing fast dissolving tablets by sublimation technique is inert solid subliming ingredients (Camphor, urea, menthol) were added to other tablet excipients and the blend was compressed into tablet. Removal of volatile material by sublimation generates a porous structure. Compressed tablets have been prepared by sublimation technique. The tablets dissolve within 20-30 secs and exhibit sufficient mechanical strength for practical use. Twelve formulations were developed by varying concentration of different subliming agent. Accurately weighed ingredients were sifted through sieve no.44 and thoroughly mixed for $10 \mathrm{~min}$ and magnesium stearate and other ingredients were added to the blend and thoroughly mixed. The tablets were compressed using Rimek tablet punching machine. The compressed tablets were than subjected to sublimation by keeping the tablets in vacuum dryer at $60^{\circ} \mathrm{C}$ for $3 \mathrm{hrs}$. The compositions of the tablets were given in Table 2.

\section{Drug + Camphor + Other Excipients}
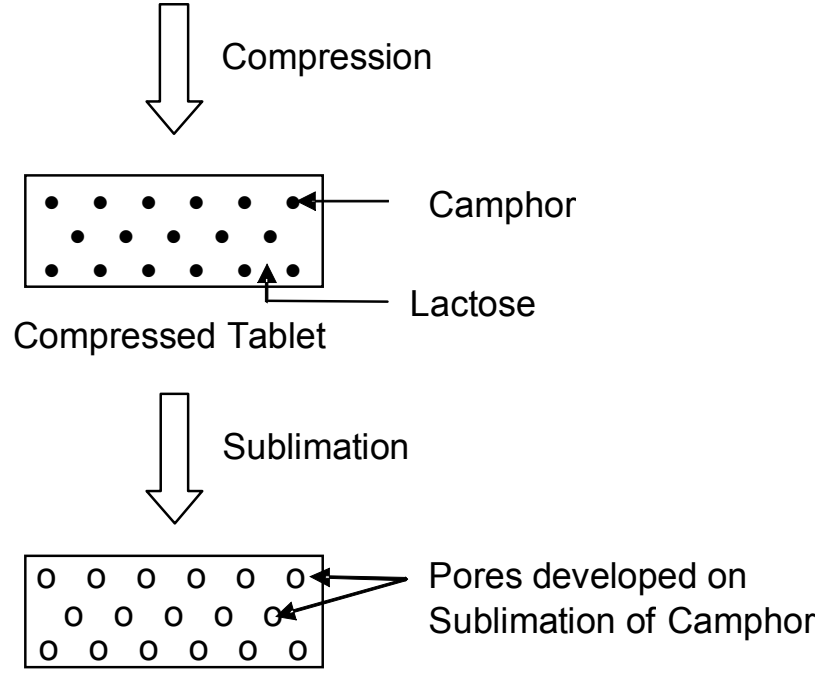

Figure 1: Schematics figure of Sublimation method for design of Mouth dissolving tablets

Micromeritic properties of powder blend of tablets before compression: The resultant blends were evaluated for precompressional parameters to find out the flow properties of powder blend. The pre-compressional parameters such as Bulk density, Tapped density, Angle of repose, Compressibility index and Hausner ratio.

Evaluation of Ondansetron HCI Fast Disintegrating Tablets The prepared tablets were subjected to post-compression analysis done according to specification given in IP 1996 for the parameters such as hardness, friability, weight variation, drug content, The in-vitro disintegration time, wetting time and invitro dissolution studies.

Hardness: Hardness of the tablet of each formulation was determined using Pfizer hardness tester.
Friability: Tablet Friability was measured using Roche Friabilator according to specification given in IP 1996. This device subjects the tablets to the combined effect of abrasions and shock in a plastic chamber revolving at $25 \mathrm{rpm}$ for $4 \mathrm{~min}$. The tablets were dedusted, and the loss in weight caused by the fracture and abrasion was recorded as the \% weight loss. Friability below $1 \%$ was considered acceptable.

Weight variation: The tablets were selected randomly from each formulation and weighed individually to check for weight variation. In all the formulations the tablet weight was more than $130 \mathrm{mg}$ and less than $324 \mathrm{mg}$, hence $7.5 \%$ maximum difference allowed.

Uniformity of drug content: A tablet was crushed and dissolved $1 \mathrm{ml}$ of dilute hydrochloric acid and $30 \mathrm{ml}$ of distilled water. This solution was shaken for $15 \mathrm{~min}$. the volume of this solution was made up to $50 \mathrm{ml}$ with distilled water and 
centrifuged. Five $\mathrm{ml}$ of the clear supernatant was mixed with 10 $\mathrm{ml}$ of $0.1 \mathrm{M} \mathrm{HCl}$, and made up to $100 \mathrm{ml}$ with distilled water. The absorption of the solution was determined spectrophotometrically at $249 \mathrm{~nm}$. The same procedure was followed for another nine tablets.

Disintegration time: Disintegration of fast dissolving tablets is achieved by saliva in the mouth, however amount of saliva in the mouth is limited and no tablet disintegration test was found in USP and IP to simulate in vivo condition. The disintegration time was measured using a modified disintegration method. According to this method, a Petri dish of $10 \mathrm{~cm}$ diameter was filled with $10 \mathrm{ml}$ of distilled water, the tablet was carefully places at the centre of the Petri dish, and the time necessary for the complete disintegration of the tablet in to fine particles was noted as disintegration time ${ }^{14}$.

Wetting time ${ }^{15}$ : The method was applied to measure tablet wetting time. A piece of tissue paper folded twice was placed in a small petri dish $(\mathrm{i} . \mathrm{d}=6.5 \mathrm{~cm})$ containing $10 \mathrm{ml}$ of water, a tablet was placed on the paper, and the time for complete wetting was measured. Three trials for each batch were performed and standard deviation was also determined.
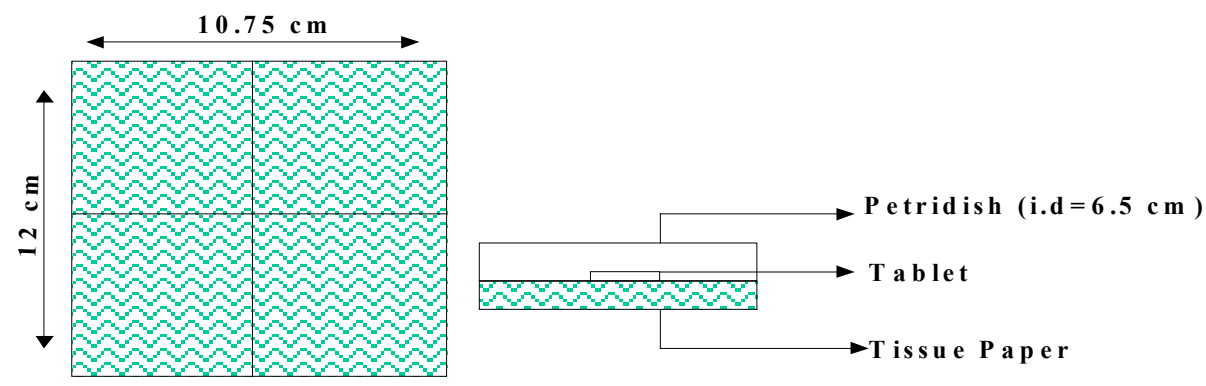

$T$ issu e $P$ aper

Figure 2: Simple method for the measurement of wetting time of a tablet

Dissolution studies ${ }^{15}$ : Tablet test condition for the dissolution rate studies were used according USP specification using USP 24, type II apparatus. The dissolution medium was $900 \mathrm{ml}$ of 0.1 $\mathrm{N} \mathrm{HCl}(\mathrm{pH}$ 1.2). The temperature of the dissolution medium and the rate of agitation were maintained at $37 \pm 0.5^{\circ} \mathrm{C}$ and $50 \mathrm{rpm}$ respectively. Aliquots of $10 \mathrm{ml}$ of dissolution medium were withdrawn at specific time interval and the volume replaced by fresh dissolution medium, pre-warmed to $37 \pm 0.5^{\circ} \mathrm{C}$. The drug concentration was determined spectrophotometrically at $249 \mathrm{~nm}$ using UV spectrophotometer (Shimadzu S 1700, Japan).

Stability studies: The purpose of stability testing is to provide evidence on how the quality of a drug substance or drug product varies with time under the influence of a variety of environmental factors such as temperature, humidity, light and enables recommended storage conditions. In the present study, stability studies were carried out as per ICH guidelines at $45^{\circ} \mathrm{C} / 75 \pm 5 \% \mathrm{RH}$ and $25^{\circ} \mathrm{C} / 75 \pm 5 \% \mathrm{RH}$ for a specific time period up to 3 months.

\section{RESULTS AND DISCUSSIONS}

Fast dissolving tablets of Ondansetron $\mathrm{HCl}$ were prepared by sublimation technique using subliming ingredients (Camphor, urea, menthol). Removal of volatile material by sublimation generates a porous structure. Compressed tablets have been prepared by using superdisintegrant like Crospovidone along with Mannitol and aspartame which serve as a sweetening agent. Drug resin complex help in masking bitter taste of the drug.

Solubility study: The solubility studies of Ondansetron Hydrochloride in water/buffer solutions were carried out to know the solubility and decide the appropriate dissolution medium. Table 1 shows the solubility data of Ondansetron $\mathrm{HCl}$ in water/ buffer solutions. In this study acidic buffer $\mathrm{pH}$ 1.2(1.2 $\mathrm{pH} 0.1 \mathrm{~N} \mathrm{HCl}$ ) was used as dissolution media as it can maintain perfect sink conditions. The solubility data for the drug in various buffers and water are shown in Table 1.

Taste evaluation: Taste evaluation was performed on six healthy human volunteers and the results were reported in the Table 3. The pure drug was felt bitter immediately after it was kept on the tongue and the sense was even carried up to $5 \mathrm{~min}$. However the bitterness of the drug was reduced or even masked after complexation with Kyron T134 in different ratios $(1: 0.5,1$ : $1,1: 2,1: 3)$. In case of 1:0.5 ratio it was felt slightly bitter after 1 min and it is apparent from the results that the increasing concentrations of the polymer have completely have completely masked the bitter taste of the drug. Since the drug is not in the native form and entrapped within the polymeric matrix, and there by reduction in the solubility of the drug in the saliva could have led to the masking of the bitter taste. Even though the Ondansetron $\mathrm{HCl}$ taste was masked with drug polymer complex $(1: 0.5,1: 1,1: 2,1: 3)$ ratios, we have selected 1:1 for further studies, since higher amounts of polymer may retard the dissolution performance of the final fast disintegrating tablets of Ondansetron $\mathrm{HCl}$.

Pre-compression parameters: Powder containing drug and various excipients were subjected for pre-compression parameters (Micromeritic properties) to study the flow properties of powder, to achieve uniformity of tablet weight. The values of pre-compression parameters evaluated were within prescribed limits and indicated good free flowing property. The results of all the preformulations parameters are shown in Table 4.

\section{Drug - Excipient compatibility studies}

FTIR Studies: The FTIR spectra of pure drug peaks are observed in the Ondansetron $\mathrm{HCl}$ sample and formulations were showed same characteristic absorption bands at or near that of Ondansetron $\mathrm{HCl}$ absorption bands values indicating that there was no chemical and physical change in the functional groups present in Ondansetron $\mathrm{HCl}$. [Shown in Figure 3]. 
N. G. Raghavendra Rao et al. Int. Res. J. Pharm. 2016, 7 (8)

Table 1: Solubility study data of ondansetron hydrochloride

\begin{tabular}{|c|c|c|c|c|}
\hline Sr. No & Solvent or Buffer & I time (mcg/ml) & II time (mcg/ml) & Average (mcg/ml) \\
\hline $\mathbf{1}$ & Water & 66.25 & 3.428 & 4.839 \\
\hline $\mathbf{2}$ & 0.1 N HCL & 17.61 & 19.24 & 18.450 \\
\hline $\mathbf{3}$ & Phosphate buffer 6.8 & 8.58 & 9.75 & 11.600 \\
\hline $\mathbf{4}$ & Phosphate buffer 7.4 & 7.445 & 9.740 & 8.592 \\
\hline
\end{tabular}

Table 2: Formula of ondansetron HCI FDT prepared by sublimation method (1-tablet)

\begin{tabular}{|c|c|c|c|c|c|c|c|c|c|c|c|c|}
\hline \multirow[t]{2}{*}{ Ingredients (mg) } & \multicolumn{12}{|c|}{ Formulations code } \\
\hline & OHS1 & OHS2 & OHS3 & OHS4 & OHS5 & OHS6 & OHS7 & OHS8 & OHS9 & OHS10 & OHS11 & OHS12 \\
\hline $\begin{array}{l}\text { Drug resin mixture } \\
\text { Equivalent to } 4 \mathrm{mg} \text { of } \\
\text { Ondansetron } \mathrm{HCl}\end{array}$ & 10 & 10 & 10 & 10 & 10 & 10 & 10 & 10 & 10 & 10 & 10 & 10 \\
\hline $\mathrm{MCC}$ & 20 & 20 & 20 & 20 & 20 & 20 & 20 & 20 & 20 & 20 & 20 & 20 \\
\hline Mannitol & 60 & 58 & 54 & 46 & 60 & 58 & 54 & 46 & 60 & 58 & 54 & 46 \\
\hline Camphor & 2 & 4 & 8 & 16 & - & - & - & - & - & - & - & - \\
\hline Urea & - & - & - & - & 2 & 4 & 8 & 16 & - & - & - & - \\
\hline Menthol & - & - & - & - & - & - & - & - & 2 & 4 & 8 & 16 \\
\hline Crosspovidone & 6 & 6 & 6 & 6 & 6 & 6 & 6 & 6 & 6 & 6 & 6 & 6 \\
\hline Mg stearate & 1 & 1 & 1 & 1 & 1 & 1 & 1 & 1 & 1 & 1 & 1 & 1 \\
\hline Talc & 1 & 1 & 1 & 1 & 1 & 1 & 1 & 1 & 1 & 1 & 1 & 1 \\
\hline Total Weight & 100 & 100 & 100 & 100 & 100 & 100 & 100 & 100 & 100 & 100 & 100 & 100 \\
\hline
\end{tabular}

Table 3: Comparative taste evaluation

\begin{tabular}{|c|c|c|c|c|c|}
\hline Form of Ondansetron HCl & $\mathbf{1 0} \mathbf{~ s e c}$ & $\mathbf{3 0} \mathbf{~ s e c}$ & $\mathbf{1} \mathbf{m i n}$ & $\mathbf{2} \mathbf{~ m i n}$ & $\mathbf{5} \mathbf{~ m i n}$ \\
\hline Pure drug & 3 & 3 & 3 & 3 & 2 \\
\hline DPC (1:0.5) & 0.5 & 1 & 1 & 1 & 0 \\
\hline DPC (1:1) & 0 & 0 & 0.5 & 0.5 & 0 \\
\hline DPC (1:2) & 0 & 0 & 0.5 & 0 & 0 \\
\hline DPC (1:3) & 0 & 0 & 0.5 & 0 & 0 \\
\hline
\end{tabular}

Table 4: Pre-Compression parameters of blend used for sublimation method

\begin{tabular}{|c|c|c|c|c|c|}
\hline $\begin{array}{c}\text { Formulation } \\
\text { code }\end{array}$ & $\begin{array}{c}\text { Bulk density* } \\
\text { (g/cc) } \pm \text { SD }\end{array}$ & $\begin{array}{c}\text { Tapped Density* } \\
\text { (g/cc) } \pm \text { SD }\end{array}$ & $\begin{array}{c}\text { Angle of repose* } \\
\text { (degree) } \\
\pm \text { SD }\end{array}$ & $\begin{array}{c}\text { Carr's Index* (\%) } \\
\pm \text { SD }\end{array}$ & $\begin{array}{c}\text { Hausner's } \\
\text { Ratio* } \\
\pm \text { SD }\end{array}$ \\
\hline OHS1 & $0.322 \pm 0.06$ & $0.420 \pm 0.01$ & $29.51 \pm 1.71$ & $16.44 \pm 1.23$ & $1.19 \pm 0.03$ \\
\hline OHS2 & $0.320 \pm 0.06$ & $0.425 \pm 0.01$ & $28.34 \pm 1.58$ & $16.31 \pm 1.02$ & $1.17 \pm 0.02$ \\
\hline OHS3 & $0.325 \pm 0.06$ & $0.428 \pm 0.01$ & $28.11 \pm 1.30$ & $15.96 \pm 1.03$ & $1.18 \pm 0.03$ \\
\hline OHS4 & $0.356 \pm 0.06$ & $0.561 \pm 0.02$ & $27.78 \pm 1.29$ & $14.68 \pm 1.25$ & $1.16 \pm 0.03$ \\
\hline OHS5 & $0.372 \pm 0.01$ & $0.425 \pm 0.01$ & $24.14 \pm 0.13$ & $21.66 \pm 1.51$ & $1.27 \pm 0.01$ \\
\hline OHS6 & $0.389 \pm 0.02$ & $0.527 \pm 0.02$ & $24.98 \pm 1.21$ & $23.25 \pm 1.59$ & $1.31 \pm 0.02$ \\
\hline OHS7 & $0.461 \pm 0.03$ & $0.551 \pm 0.02$ & $23.11 \pm 1.07$ & $17.97 \pm 1.19$ & $1.20 \pm 0.03$ \\
\hline OHS8 & $0.376 \pm 0.04$ & $0.558 \pm 0.02$ & $20.29 \pm 1.26$ & $19.20 \pm 1.08$ & $1.24 \pm 0.01$ \\
\hline OHS9 & $0.401 \pm 0.09$ & $0.425 \pm 0.02$ & $24.14 \pm 1.20$ & $21.66 \pm 0.60$ & $1.27 \pm 0.02$ \\
\hline OHS10 & $0.401 \pm 0.15$ & $0.327 \pm 0.03$ & $24.98 \pm 1.55$ & $23.24 \pm 0.75$ & $1.31 \pm 0.04$ \\
\hline OHS11 & $0.396 \pm 0.02$ & $0.556 \pm 0.02$ & $23.12 \pm 1.42$ & $16.98 \pm 1.23$ & $1.20 \pm 0.01$ \\
\hline OHS12 & $0.350 \pm 0.13$ & $0.659 \pm 0.01$ & $21.56 \pm 1.35$ & $19.73 \pm 0.67$ & $1.24 \pm 0.07$ \\
\hline
\end{tabular}

* Average of three determinations

Table 5: Post compression parameters of tablets prepared by sublimation method

\begin{tabular}{|c|c|c|c|c|c|c|c|}
\hline \multirow[t]{2}{*}{ FC } & \multicolumn{7}{|c|}{ Parameters } \\
\hline & $\begin{array}{c}\text { Hardness } \\
\left.{ }^{2}\right) \\
\left(\mathrm{kg} / \mathrm{cm}^{2}\right. \\
\pm \mathrm{SD}\end{array}$ & $\begin{array}{l}\text { Friability } \\
(\%)\end{array}$ & $\begin{array}{c}\text { Weight } \\
\text { variation } \\
(\mathrm{mg}) \pm \mathrm{SD}\end{array}$ & $\begin{array}{c}\text { In-vitro } \\
\text { disintegration } \\
\text { time* } \\
(\mathrm{sec}) \pm \mathrm{SD}\end{array}$ & $\begin{array}{c}\text { Wetting } \\
\text { time }^{*} \\
(\text { sec }) \pm \text { SD }\end{array}$ & $\begin{array}{c}\text { Water } \\
\text { absorption } \\
\text { ratio }^{*}(\%)^{ \pm} \text {SD }\end{array}$ & $\begin{array}{l}\text { Drug Content* } \\
(\%) \pm \text { SD }\end{array}$ \\
\hline OHS1 & $3.0 \pm 0.20$ & 0.72 & $101 \pm 0.20$ & $51 \pm 1.0$ & $61 \pm 210$ & $72 \pm 1.34$ & $100.48 \pm 1.21$ \\
\hline OHS2 & $2.9 \pm 0.10$ & 0.61 & $100 \pm 0.40$ & $46 \pm 1.4$ & $57 \pm 210$ & $74 \pm 1.31$ & $99.98 \pm 1.41$ \\
\hline OHS3 & $2.8 \pm 0.21$ & 0.52 & $100 \pm 0.45$ & $42 \pm 1.2$ & $49 \pm 135$ & $81 \pm 1.73$ & $99.99 \pm 055$ \\
\hline OHS4 & $2.7 \pm 0.05$ & 0.42 & $99 \pm 0.55$ & $28 \pm 2.1$ & $40 \pm 1.79$ & $85 \pm 1.54$ & $99.99 \pm 1.53$ \\
\hline OHS5 & $3.0 \pm 0.11$ & 0.65 & $101 \pm 0.34$ & $66 \pm 1.50$ & $77 \pm 1.00$ & $73 \pm 1.24$ & $98.24 \pm 0.22$ \\
\hline OHS6 & $3.0 \pm 0.10$ & 0.55 & $100 \pm 0.20$ & $58 \pm 1.0$ & $69 \pm 1.42$ & $72 \pm 1.09$ & $100.19 \pm 0.34$ \\
\hline OHS7 & $2.9 \pm 0.15$ & 0.61 & $101 \pm 0.40$ & $52 \pm 1.7$ & $63 \pm 189$ & $72 \pm 1.12$ & $100.80 \pm 1.63$ \\
\hline OHS8 & $2.8 \pm 0.10$ & 0.59 & $99 \pm 0.45$ & $32 \pm 1.0$ & $44 \pm 1.15$ & $82 \pm 1.14$ & $989.1 \pm 1.16$ \\
\hline OHS9 & $3.0 \pm 0.10$ & 0.73 & $100 \pm 0.55$ & $70 \pm 1.1$ & $81 \pm 1.48$ & $74 \pm 1.12$ & $99.9 .3 \pm 1.42$ \\
\hline OHS10 & $3.0 \pm 0.15$ & 0.61 & $101 \pm 0.34$ & $68 \pm 1.7$ & $78 \pm 1.89$ & $73 \pm 1.12$ & $100.80 \pm 1.3$ \\
\hline OHS11 & $2.9 \pm 0.11$ & 0.55 & $101 \pm 0.34$ & $61 \pm 1.50$ & $71 \pm 1.00$ & $74 \pm 1.24$ & $98.2 .3 \pm 0.22$ \\
\hline OHS12 & $2.7 \pm 0.20$ & 0.42 & $99 \pm 0.20$ & $50 \pm 1.00$ & $62 \pm 210$ & $73 \pm 1.34$ & $101.20 \pm 34$ \\
\hline
\end{tabular}




\begin{tabular}{|c|c|c|c|c|}
\hline Sr. No. & Formulation code & $\begin{array}{c}\text { In-vitro } \\
\text { disintegration time }(\mathrm{sec}) \pm \mathrm{SD}\end{array}$ & $\begin{array}{l}\text { Wetting time } \\
\text { (sec) } \pm \text { SD }\end{array}$ & $\begin{array}{l}\text { Drug content } \\
(\%) \pm \text { SD }\end{array}$ \\
\hline \multicolumn{5}{|c|}{$25 \pm 2^{0} \mathrm{C}, 60 \% \pm 5^{0} \mathrm{C} \% \mathrm{RH}$} \\
\hline 1 & OHS4 & $28 \pm 1.00$ & $40 \pm 1.00$ & $99.87 \pm 1.32$ \\
\hline 2 & OHS8 & $32 \pm 1.94$ & $44 \pm 1.24$ & $98.61 \pm 0.37$ \\
\hline 3 & OHS12 & $50 \pm 1.34$ & $62 \pm 2.56$ & $101.37 \pm 0.56$ \\
\hline \multicolumn{5}{|c|}{$40 \pm 2^{0} \mathrm{C}, 75 \% \pm 5^{0} \mathrm{C} \% \mathrm{RH}$} \\
\hline 4 & OHS4 & $27 \pm 1.12$ & $38 \pm 1.22$ & $99.67 \pm 1.36$ \\
\hline 5 & OHS8 & $30 \pm 1.00$ & $41 \pm 1.21$ & $98.60 \pm 0.37$ \\
\hline 6 & OHS12 & $49 \pm 1.27$ & $59 \pm 1.17$ & $101.30 \pm 0.55$ \\
\hline
\end{tabular}

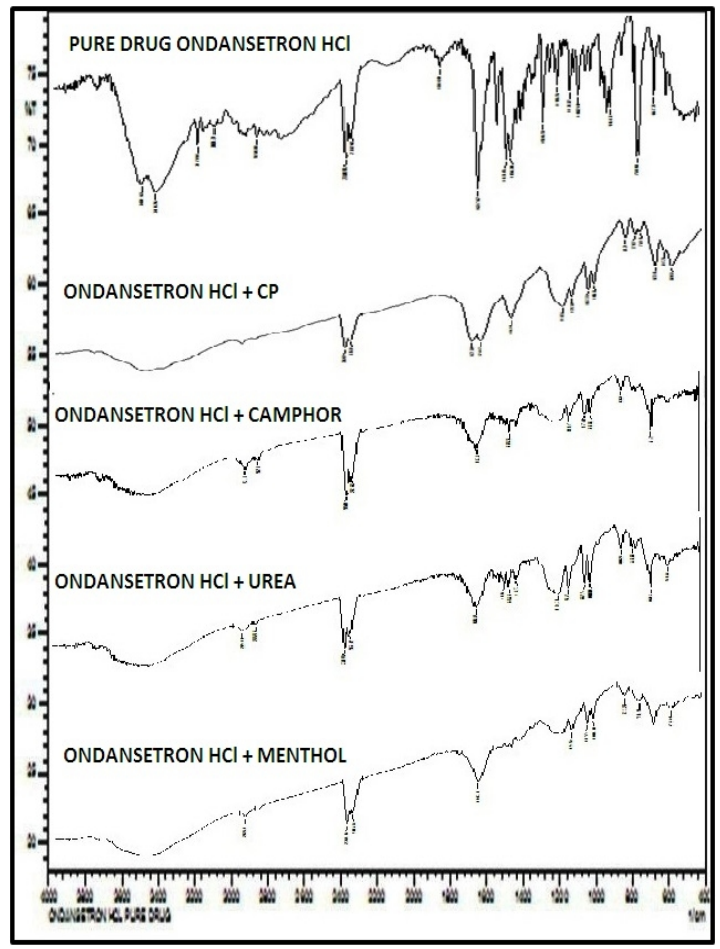

Figure 3: IR spectra of pure drug Ondansetron $\mathrm{HCl}$ and Drug with additives

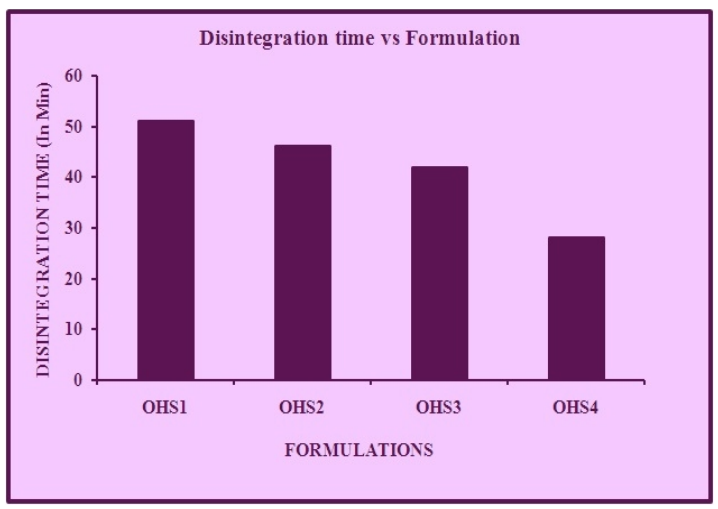

Figure 5: Comparison of Disintegration time of different formulation prepared by Camphor

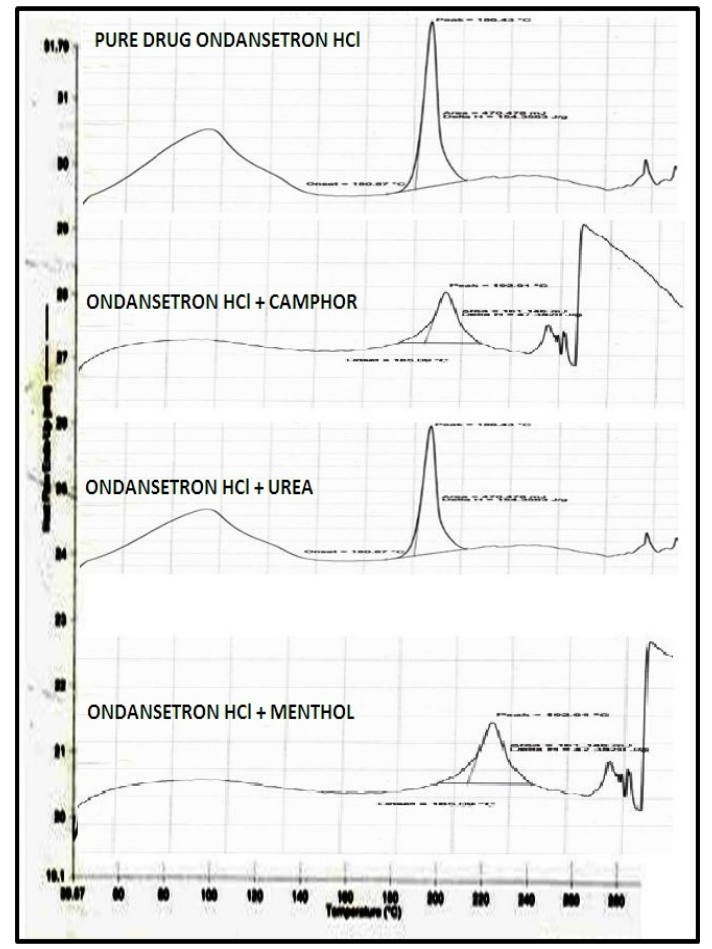

Figure 4: DSC spectra of pure drug Ondansetron $\mathrm{HCl}$ and Drug with additives

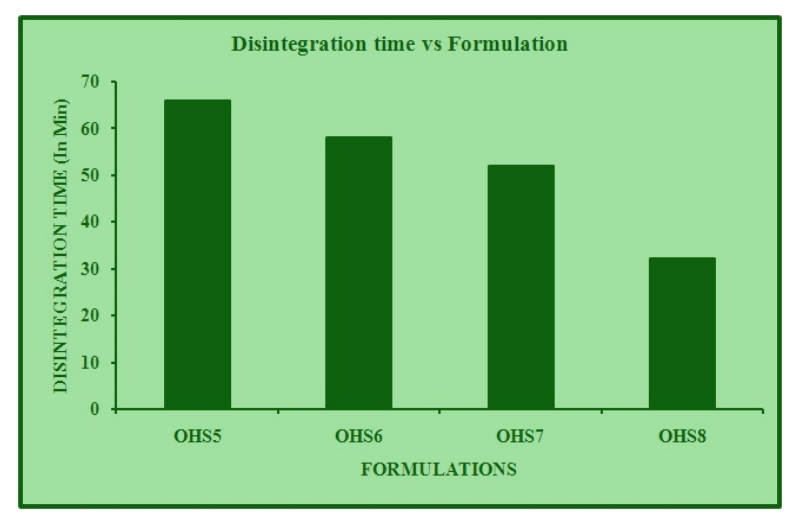

Figure 6: Comparison of Disintegration time of different formulation prepared by Urea 


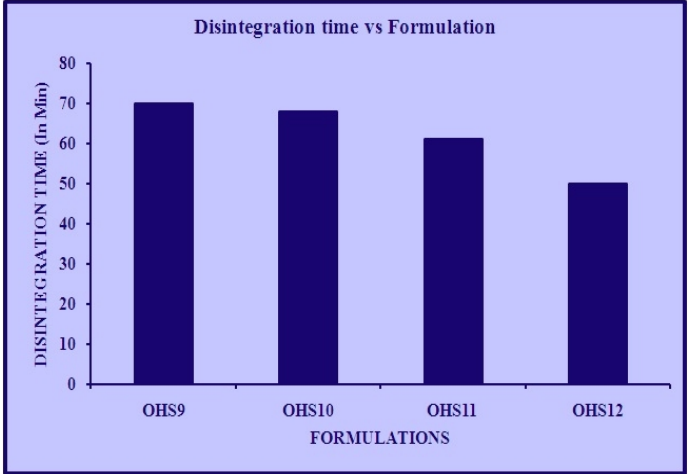

Figure 7: Comparison of Disintegration time of different formulation prepared by Menthol

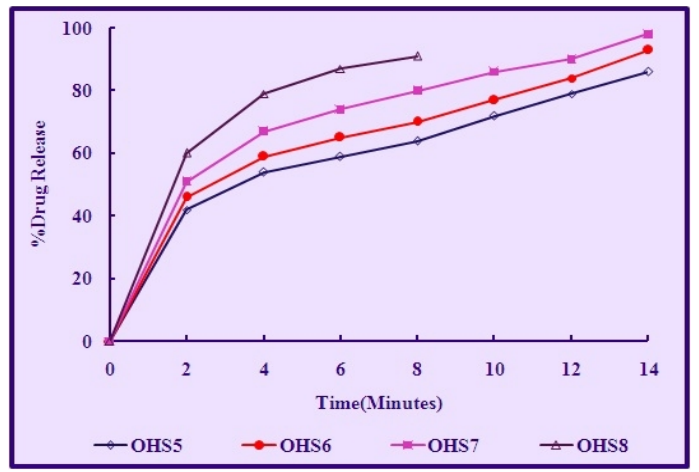

Figure 7: Release profile of the Ondansetron HCI FDT Prepared by Sublimation method by using Urea

DSC Studies: The study also reveals that the thermogram of pure drug and other formulations [Shown in Figure 4] shows negligible changes in the melting point range. Thus the DSC Thermograms study reveals that there is no any kind of interaction of the drug with different types of polymer and their excipients used during the study.

The results of post-compressional parameters were within I.P prescribed limits. The results of post-compression parameters were given in Table 5. The hardness of the tablets prepared by sublimation method was maintained in the range of 2.70 $\mathrm{kg} / \mathrm{cm}^{2}$ to $3.00 \mathrm{~kg} / \mathrm{cm}^{2}$. From the hardness analysis data it was observed that, there was decrease in hardness of the tablet when we increased the concentration of subliming agent in tablets prepared by sublimation method. The friability result were found in all designed formulations in the range of 0.42 to $0.73 \%$ to be well within the approved range $(<1 \%)$. The friability results were found in the range of 0.42 to $0.73 \%$. The weight variation was found in 99 to $101 \mathrm{mg}$ in sublimation method. The mean weight variation test results are tabulated in table no.5. All the tablets passed weight variation test as the average percentage weight variation was within $7.5 \%$ i.e. in the pharmacopoeia limits.

Wetting time is closely related to the inner structure of the tablet. The wetting time of Ondansetron $\mathrm{HCl}$ fast dissolving tablets prepared was found to be in the range of 44 to $81 \mathrm{sec}$. The prepared formulations shows water absorption ratio in the range of 72 to $85 \%$. The percentage drugs content of the tablets were found to be between 98.24 to $101.20 \%$ of Ondansetron $\mathrm{HCl}$. The results were within the range and indicate uniformity of mixing. The values of water absorption

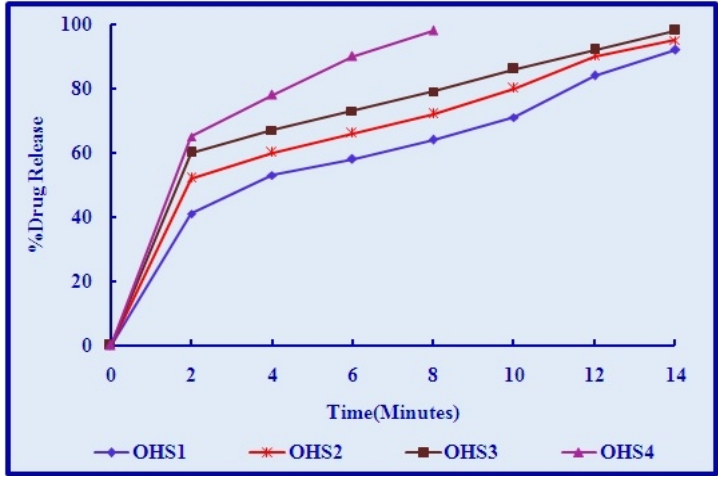

Figure 6: Release profile of Ondansetron HCI FDT Prepared by Sublimation method by using Camphor

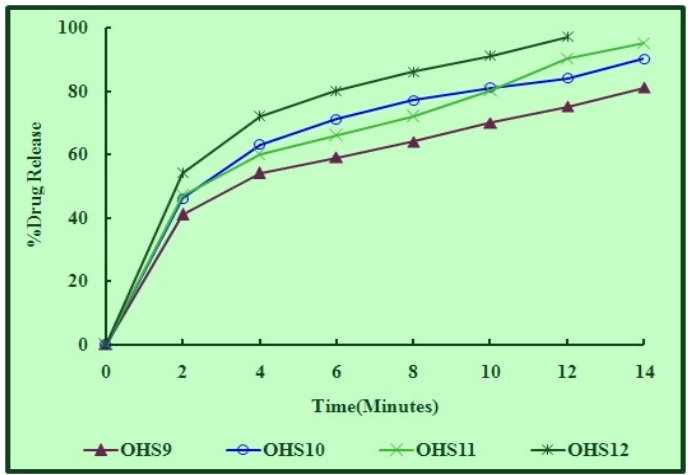

Figure 8: Release profile of the Ondansetron HCl FDT Prepared by Sublimation method by using Menthol

ratio and drug content were showed in Table 5 .

In-vitro disintegration (Figure 5-7) time and dissolution studies formulations OHS4 and OHS8 were found to be promising and showed a disintegration time of $28 \mathrm{sec}$ and $32 \mathrm{sec}$ respectively. This may be due to their lowest hardness and the porous structure is responsible for faster water uptake ${ }^{16}$. Crospovidone containing tablets rapidly exhibits high capillary activity and pronounced hydration with a little tendency to gel formation and disintegrate the tablets rapidly ${ }^{17}$.

The Ondansetron $\mathrm{HCl}$ promised formulations OHS4, OHS8, OHS12 shows nearly faster drug release. The formulation OHS4, OHS8, and OHS12 $90 \%$ of drug released in $6 \mathrm{~min}$, $8 \mathrm{~min}$ and $10 \mathrm{~min}$ respectively when compare to other formulation. All these promised formulations contacting maximum concentration of volatile component i.e. OHS4 contain $16 \%$ camphor, OHS 8 contain $16 \%$, urea and OHS12 contains $16 \%$ menthol. This leads to formation of more pores within the tablets ${ }^{18}$. The result also revealed that, all the formulations were having enough mechanical strength, low wetting and disintegration time and good mouth fee $1^{19}$. All the formulations were having good mouth feel because all the tablets were fabricated using mannitol as filler will produce sweetness and negative heat of solution, which leaves a pleasant, cooling sensation in mouth ${ }^{20}$. The dissolution release profiles of Ondansetron $\mathrm{HCl}$ from the tablets are shown in (Figure 8-10). The tablets prepared by sublimation technique, the dissolution rate of tablet were increase with increase in concentration of camphor. Formulation OHS4 containing camphor showed highest drug release $99 \%$ in $8 \mathrm{~min}$. This may be due to their lowest hardness and the porous structure was responsible for 
faster water uptake, hence it facilitates wicking action of Crospovidone in bringing about faster disintegration.

Based on the in-vitro disintegration time and dissolution studies formulations OHS4 and OHS8 were found to be promising and showed a disintegration time of $28 \mathrm{sec}$ and $32 \mathrm{sec}$ respectively. Formulation OHS4 containing camphor showed highest drug release 99\% within 8 min. Formulation OHS8 showed highest drug release $90 \%$ within $8 \mathrm{~min}$. This may be due to their lowest hardness and the porous structure was responsible for faster water uptake, hence it facilitates wicking action of Crospovidone in bringing about faster disintegration.

The promising formulations (OHS4, OHS8 and OHS12) were subjected to stability study by storing the formulations at $25 \pm$ $2^{0} \mathrm{C} 60 \% \pm 5 \% \mathrm{RH}$ and $40 \pm 2^{0} \mathrm{C}, 75 \pm 5 \% \mathrm{RH}$ up to one month in the stability chamber. After one month the formulations were taken from the chamber and investigated the parameters (Table 6). In case of stability study at $40{ }^{0} \mathrm{C}, 75$

$\mathrm{RH}$ there is decrease in disintegration time, wetting time were observed in formulations prepared by this method. It may be due to formation of extra pore in the tablet texture due to removal of trace amount of volatile substance.

\section{CONCLUSION}

The above results concluded that, the fast dissolving tablets of Ondansetron $\mathrm{HCl}$ showing enhanced dissolution may lead to improved bioavailability and effective therapy by using sublimation method. Based on the in-vitro disintegration time and dissolution studies formulations OHS4 and OHS8 were found to be promising and showed a disintegration time of 28 $\mathrm{sec}$ and $32 \mathrm{sec}$ respectively. Formulation OHS4 containing camphor showed highest drug release $99 \%$ within 8 min. Formulation OHS 8 showed highest drug release $90 \%$ within 8 min. This may be due to their lowest hardness and the porous structure was responsible for faster water uptake, hence it facilitates wicking action of crosspovidone in bringing about faster disintegration

\section{REFERENCES}

1. Bi YX, Sunada H, Yonezawa Y, Danjo K. Evaluation of rapidly disintegrating tablets prepared by direct compression method. Drug Dev Ind Pharm.1999; 25:571-581.

2. Chue P, Welch R, Binder C. Acceptability and disintegration rates of orally disintegrating Risperidone tablet in patients with schizophrenia or chizoaffective disorder. Can. Jr. Psychiatry. 2004; 49:701-3

3. Shu T, Suzuki H, Hirohonda K, Ito K. Studies of rapidly disintegrating tablets in oral cavity using co ground mixture of mannitol with Crosspovidone. Chem. Pharm. Bull. (Tokyo). 2002; 50:193-8

4. Seager $H$, Drug delivery products and the zydis fast dissolving dosage form. Jr. Pharm. Pharmacol. 1998; $50: 375-8$

5. Fini Adamo, Valentina Bergamanate, Gian Carlo Ceschel, Celestino Ronchi, Carlos Alberto Fonseca de Moraces, Fast dispersible/slow releasing ibuprofen tablets, Eur.Jr. Pharm. And biopharm. 2007: 335-341.

6. Seong Hoon Jeong, Yuuki Takaishi, Yourong fu and Kinam Park. Material properties for making fast dissolving tablet by a compression method. J. Mater. Chem. 2008; 18:3527-3535.
7. Debjit Bhowmik, Chiranjib, Joti Jaiswal, Vinod Dubey, Margret Chandira. Fast dissolving tablet: A review on revolution of novel drug delivery system and new market opportunities. Scholar Research Library Der Pharmacia Lettre. 2009; 1(2): 262-276.

8. Alanazi FK, Alsarra IA. Formulation and physicochemical characterization of buccoadhesive films containing Ondansetron Hydrochloride. J.Drug Del.Sci, 2007; 17(3): $183-192$.

9. Salem II, Lopez, JMR, Galan AC. Ondansetron hydrochloride. In: Analytical Profiles of Drug Substances and Excipients. Brittain HG, Editor; California, 2001; 301308.

10. Joshi AA, Xavier D. Added functionality excipients. Pharm Technol (Excipients and solid dosage forms) 2004; 12-9.

11. Sallam E, Ibrahim H, Abu Dahab R, Shubair M, Khalil E. Evaluation of fast dissintegrants in terfenadine tablets containing a gas-evolving disintegrant. Drug Dev Ind Pharm. 1998; 24:501-507.

12. Srikanth Reddy M, Raghavendra Rao NG, Krishna. D. Formulation and Design of Taste Masked Quetiapine Fumarate Orally Fast Disintegrating Tablets by Sublimation Method. Indo American Journal of Pharmaceutical Research. IAJPR: Vol 2, Issue 12, 2013: 1446-1461.

13. Srikanth Reddy M, Raghavendra Rao NG, Krishna. D. Formulation and Design of Taste Masked Quetiapine Fumarate Orally Fast Disintegrating Tablets. Asian Journal of Pharmaceutical and Clinical Research. AJPCR: Vol 6, Issue 2, 2013, 70-75.

14. Venkatesh K, Shravani B, Gampa Vijaya Kumar, Raghavendra Rao NG. Formulation and Evaluation Baclofen Fast Dissolving Tablets by Vacuum Drying Technique. Indo american Journal of Pharmaceutical Research. IAJPR: Vol 3, Issue 5, 2013:3721-3733.

15. N. G. Raghavendra Rao, Mahesh Kumar, Mettu Srikanth Reddy, B. Mahipal Reddy, C. Kistayya. Development and Evaluation of Fast Dissolving Tablets of Fosinopril by Direct Compression Method. Int. Res. J. Pharm. 2012:3(10):123-129.

16. Hariprasanna RC, Bhavik P. Formulation and development of fast disintegrating Felodipine tablets: Functionality of superdisintegrants. IJPSR, 2010; 1(8): 93-99.

17. Kulkarni Upendra, Karkar Vipul. Formulation and optimization of fast dissolving Meloxicam tablets by Vacuum drying technique. IJPSR, 2010; 1(8): 133-138.

18. Raghavendra Rao NG, Ravi Kumar K. Comparative study on effect of different subliming agents on fast dissolving tablets of Chlorthalidone by vacuum drying technique. IJPSR, 2010; 1(8): 78-87.

19. Setty CM. Comparative study on effect of different techniques used in the Formulation of Felodipine fast dissolving tablets. Int.J.Pharmacy Pharm.sci. 2010; 2(2): 152-159.

20. Korwar PG, Soodam SR. Formulation and evaluation of fast dispersible tablets of Sertraline using different superdisintegrants. Int. Res. J. Pharm. 2010; 1(1): 132-137.

\section{Cite this article as:}

N. G. Raghavendra Rao, B. Sanjeeva Nayak, B. Santhosh Kumar, C. Kistayya. Design and development of taste masked oral disintegrating tablet of ondansetron hydrochloride. Int. Res. J. Pharm. 2016;7(8):58-64 http://dx.doi.org/10.7897/22308407.07897

Source of support: Nil, Conflict of interest: None Declared

Disclaimer: IRJP is solely owned by Moksha Publishing House - A non-profit publishing house, dedicated to publish quality research, while every effort has been taken to verify the accuracy of the content published in our Journal. IRJP cannot accept any responsibility or liability for the site content and articles published. The views expressed in articles by our contributing authors are not necessarily those of IRJP editor or editorial board members. 